\title{
The Hebrew Exodus from and Jeremiah's Eisodus into Egypt in the Light of Recent Archaeological and Geological Developments ${ }^{1}$
}

\author{
Prof. James K. Hoffmeier \\ Emeritus Professor of Near Eastern Archaeology and Old Testament Studies \\ Trinity Evangelical Divinity School \\ jhoffmei@tiu.edu
}

\begin{abstract}
Egyptian texts mention two bodies of water on Egypt's eastern frontier with Sinai, šs-hr and p3 twfy, the latter of which is mentioned in connection with the Exodus (as ים- - yam suf), while the former occurs in Jeremiah 2:18. Recent palaeoenvironmental work conducted by the North Sinai Archaeological Project, which was in the field from 1998 to 2008 and directed by the author, has shed new light on these bodies of water and the roles they played in the biblical events involving entering and departing Egypt. The 2019 publication of the geological data now allows one to offer some insights into these ancient lakes. Supplemented by new archaeological discoveries, elements of the routes of both journeys can be elucidated.
\end{abstract}

\section{Introduction}

A surprising number of biblical narratives contain reports of travel between Canaan/Israel and Egypt. The book of Genesis records several such accounts, including those of Abraham, Hagar, Joseph, and Jacob. Since most of these journeys began in the Negev (or specifically at Beersheba), the route taken was almost certainly 'the Way of Shur' (cf. Gen 16:7: דֶרִּד שוּר - derek shur)² which crossed Sinai, running parallel to the Mediterranean coast forty to sixty kilometres to its south, and which then entered Egypt through the Wadi Tumilat (see Figs. 1 and

1. The Tyndale Fellowship Biblical Archaeology Lecture 2021.

2. Anson Rainey, The Sacred Bridge (Jerusalem: Carta, 2006), 113-114; Menashe Har-el, The Sinai Journeys: The Route of the Exodus (Los Angeles: Ridgefield Publishing, 1983), 74. 


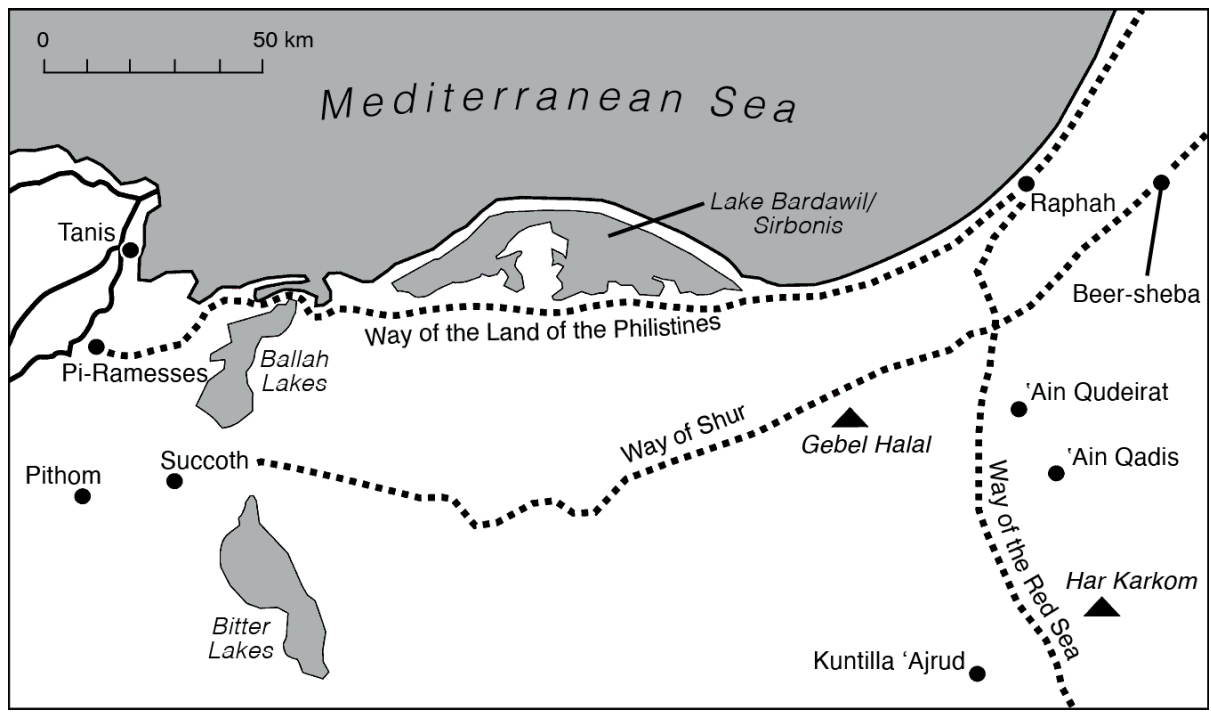

Figure 1: North Sinai, showing routes out of Egypt. (Adapted by A. D. Riddle from a map by Jessica Hoffmeier Lim.)

3). ${ }^{3}$ Hence the term 'inland route' is sometimes used to describe this little-known track. The Way of Shur is not attested in other texts apart from the Bible. Recent investigations of this road using advanced satellite imagery have helped to clarify sections of the route, which have the potential to lead to ground truthing and the discovery of archaeological sites. ${ }^{4}$

The route taken by the Ishmaelites with young Joseph was more likely the coastal highway, but details in Genesis 37 to confirm Anson Rainey's suggestion are lacking. ${ }^{5}$ The Bible knows this coastal route that runs south of Lake Bardawil as

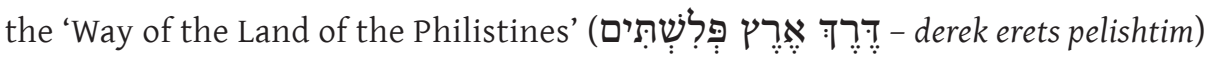
in Exodus 13:17. This ancient road has long been associated with what Sir Alan Gardiner a century ago called 'the ancient military road between Egypt and

3. For further treatment of this route, see James K. Hoffmeier and Stephen O. Moshier, "'A Highway out of Egypt": The Main Road from Egypt to Canaan' in Desert Road Archaeology in Ancient Egypt and Beyond, ed. F. Förster and H. Reimer (Africa Praehistorica 27, Köln: Heinrich-Barth-Institut, 2013), 485-490.

4. Christopher Stewart, Kris Lemmens, and Maura Sala, 'Satellite Radar in Support to Archaeological Research in Egypt: Tracing Ancient Tracks Between the Southern Levant Across North Sinai', Archaeological Heritage and Multidisciplinary Egyptological Studies 2 (2015): 199-221.

5. Rainey, The Sacred Bridge, 114-115. 
Palestine', which he equated with the Egyptian toponym 'the Way(s) of Horus' w3 $(w) t h r{ }^{6}$

The focus of the present study is on the recent geological and archaeological work on the north-eastern frontier of Egypt and north-western Sinai, that is, the Suez Canal zone from Ismailiya north to the Qantara-Pelusium region. Since the 1980s, a burst of research has been conducted in this area, spurred on by the agricultural development of the deserts of north Sinai associated with the establishment of the Al-Salam Canal, which runs east and close to the line of the ancient coastal road.

\section{The Hebrew Exodus}

In my 2011 Tyndale Fellowship lecture, I addressed some of the archaeological developments that have elucidated some aspects of the geography of the exodus narratives. Since our work at Tell el-Borg has now been fully published, including two volumes of the final report, Tell el-Borg I (2015) and Tell el-Borg II (2019), it will not be treated in detail here. As interesting as the archaeological work is for Egypt's eastern frontier defence network in the New Kingdom or Late Bronze Age, ${ }^{7}$ it is the newly published palaeoenvironmental features and the changes which occurred in this area between the second and first millennia that will be our focus. The new data permit us to understand better two important biblical travel narratives, viz, the exodus from Egypt and eisodos of Jeremiah and the band of Judaean exiles who sought refuge in Egypt after the assassination of Gedaliah (2 Kgs 25:22-26; Jer 40).

From Egyptian and biblical texts, it has long been known that several sizeable lakes were located in Egypt's north-eastern Delta and the Isthmus of Sinai. From

6. A. H. Gardiner, 'The Ancient Military Road Between Egypt and Palestine', JEA 6 (1920): 99-116, https://doi.org/10.1177/030751332000600112. While most Egyptologists maintain that 'the Ways of Horus' is the name of the road from the north-east Delta to Sinai (and across it?), Dominique Valbelle has argued strenuously for w3(w)t hr being the name of the region, not the route through it; see 'La (les) route(s)-d'Horus' in Hommages à Jean Leclant, vol. 4, ed. C. Berger, G. Clerc, and N. Grimal (Cairo: IFAO, 1994), 379-386. Not satisfied that other scholars have followed her interpretation, she has recently written again on this matter: see Dominique Valbelle, 'One More Time - "The Ways of Horus"' in Guardian of Ancient Egypt: Studies in Honor of Zahi Hawass, vol. 3, ed. J. Kramin et. al. (Prague: Charles University, 2020), 1607-1613.

7. James K. Hoffmeier, 'Reconstructing Egypt's Eastern Frontier Defense Network in the New Kingdom (Late Bronze Age)' in The Power of Walls: Fortifications in Ancient Northeastern Africa, ed. F. Jesse and C. Vogel (Colloquium Africanum 5; Köln: Heinrich-BarthInstitut, 2013), 163-194. 


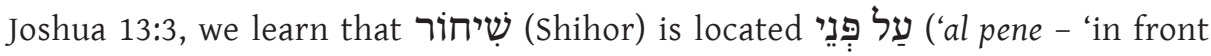
of' or 'before') Egypt. Similarly, Jeremiah 2:18 situates Shihor on Egypt's eastern frontier and will be discussed further below. The Hebrew שיחוֹis the writing for the Egyptian toponym $p 3$ šhr ( Shihor has been rendered as 'Nile' (RSV, ESV, NET) and 'Shihor Nile' (NIV). Manfred Bietak's 1975 map of the Delta identified the north-easternmost stretch of the Bubastite (later the Pelusiac) branch of the Nile as $p 3$ š-hr which emptied into a lake with the same name (Fig. 2). ${ }^{10}$ The later identification comes from Pap. Anastasi III in which $p 3$ š-hr is a location from which water plants are brought to the capital, Pi-Ramesses: " $p 3$ twfy comes to it with rushes (mnhw) and the Lake of Horus ( $p 3$ šhr) with reeds (isyw). ${ }^{11}$ The parallelism in this line suggested to Sir Alan Gardiner that the two bodies of water were geographically proximate. Bietak agreed, proposing that $p 3$ š $h r$ (Shihor) was the lake east of Qantara East and south-west of Pelusium, ${ }^{12}$ and that $p 3$ twfy is the now-defunct Ballah Lakes that run south about twenty kilometres from modern Qantara to just north of Ismailiya (Fig. 2-3).

The correspondence between $p 3$ twfy and Hebrew ים־י- (yam suf) has long been recognised and it is agreed that the word applies to a variety of water plants. ${ }^{13}$

8. Yoshiyuki Muchiki, Egyptian Proper Names and Loanwords in North-West Semitic (Atlanta: Society of Biblical Literature, 1999), 235; HALOT 1477.

9. I followed the conventional understanding when I wrote the entry 'Shihor' in ISBE 4, 476 in 1988, and since changed my view. Shihor in the old Testament is the eastern frontier lake.

10. Manfred Bietak, Tell el Dab'a II (Vienna: Österreichische Akademie der Wissenschaften, 1975), figs 10, 23.

11. Translation my own based on the text edition in Alan Gardiner, Late-Egyptian Miscellanies, Bibliotheca Aegyptiaca 7 (Brussels: Fondation Égyptologique Reine Élisabeth, 1937), 22, 15-16 = lines 2, 11-12.

12. Bietak, Tell el Dab'a II, figs 10, 23. More recently see Manfred Bietak, Avaris, the Capital of the Hyksos: Recent Excavations at Tell el-Dab'a (London: The British Museum, 1996), fig. 1 and idem., 'On the Historicity of the Exodus: What Egyptology Today Can Contribute to Assessing the Biblical Account of the Sojourn in Egypt' in Israel's Exodus in Transdisciplinary Perspective: Text, Archaeology, Culture, and Geoscience, ed. T. E. Levy, T. Schneider, and W. H. C. Propp (Cham: Springer, 2015), 17-37, https://doi.org/10.1007/978-3-319-04768-3_2.

13. Heinrich Brugsch, Hieroglyphische-Demotisches Wörterbuch IV (Leipzig: J. C. Hinrichs, 1868), 1580-1581; Max Müller, 'A Contribution to the Exodus Geography', Proceedings of the Society of Biblical Archaeology 10 (1888): 474; Alan H. Gardiner, Ancient Egyptian Onomastica II (London: Oxford University Press, 1947), 202*; Thomas O. Lambdin, 'Egyptian Loan Words in the Old Testament', JAOS 73 (1953): 153, https://doi.org/10.2307/595204; Muchiki, Egyptian Proper Names, 251. 


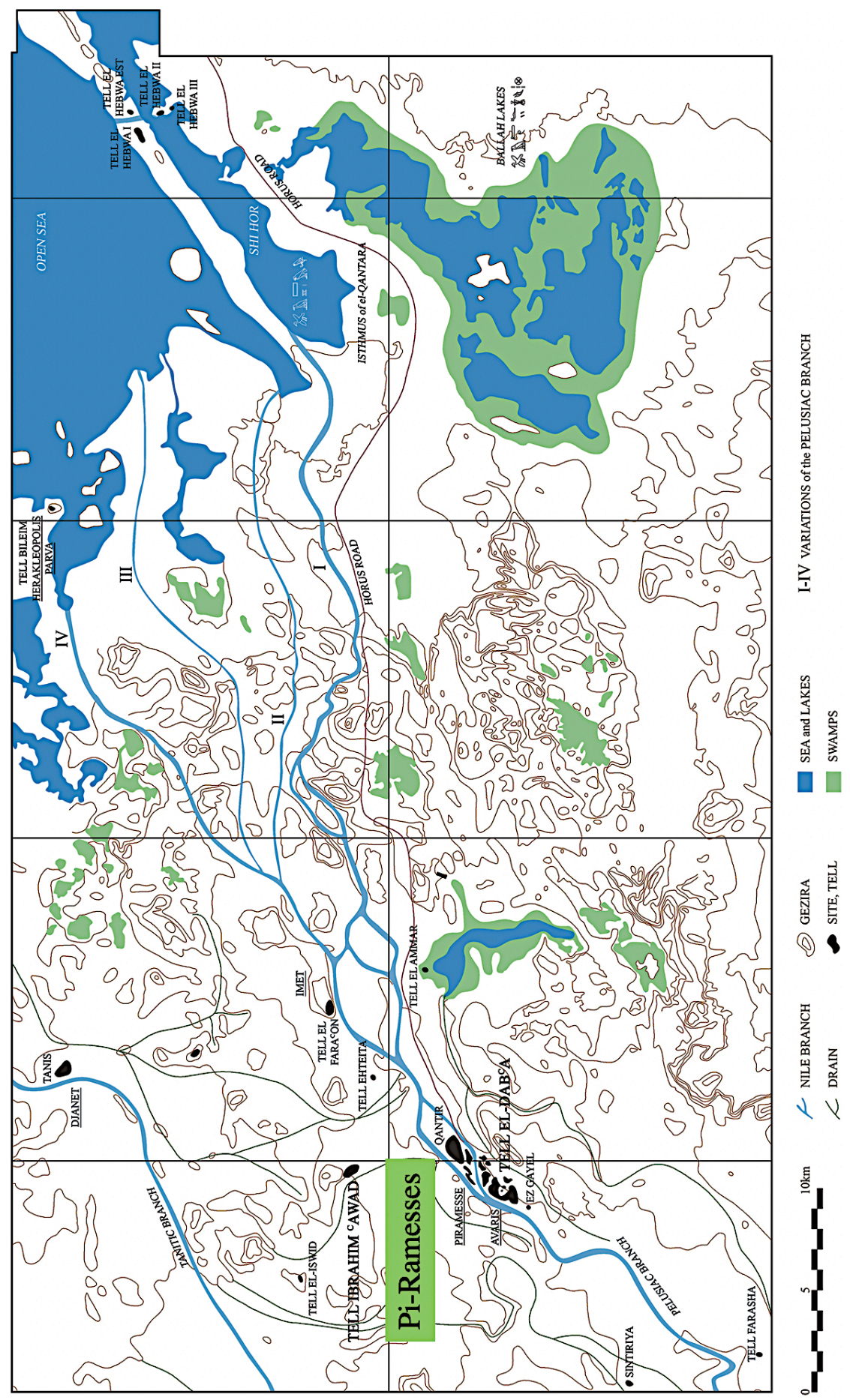

Figure 2: Manfred Bietak's map of the North-East Delta showing the Ballah Lakes and Eastern Lagoon. (Provided by, and used with permission of, Manfred Bietak.) 


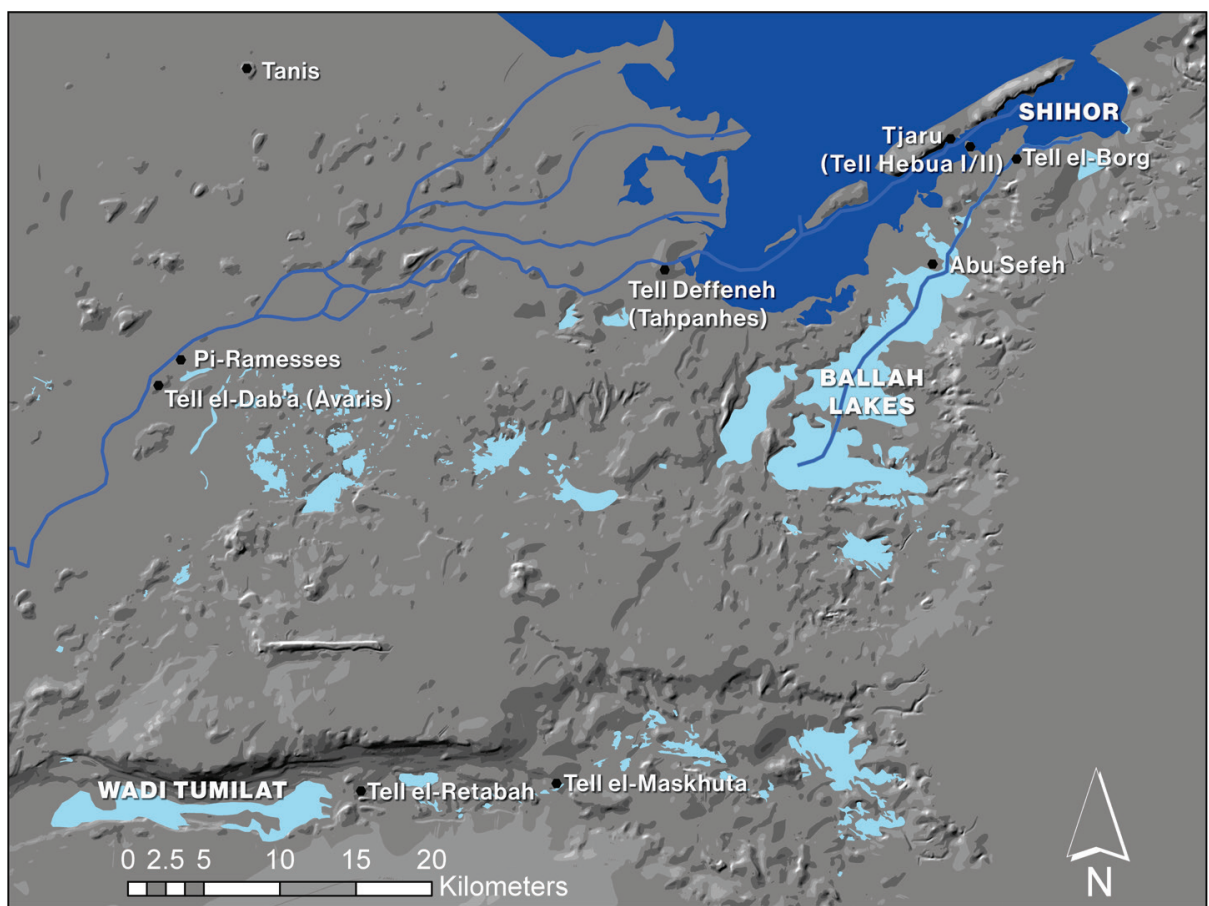

Figure 3: Topographical map of the North-East Delta with new Nile distributaries from the Ballah Lakes. (Adapted from map provided by Stephen O. Moshier.)

The only remaining linguistic question is whether it is a Semitic word come into Egyptian or an Egyptian word that made its way into the Hebrew Bible. ${ }^{14}$

Bietak's location for $p 3$ twfy is supported by the reference in the Onomasticon of Amenemope, which lists Egyptian city or town ( $d m i)$ names starting on the southern frontier with Biggah Island (\#313) and Elephantine Island (\#314). ${ }^{15}$ The final and north-easternmost townsite is Tjaru/Sile (\#419), which has been discovered at Tell Hebua (west of Shihor) with two massive New Kingdom forts

14. William Ward, 'The Biconsonantal Root $s p$ and the Common Origin of Egyptian čWf and the Hebrew Sûp: "Marsh(-Plant)", VT 24 (1974): 339-349, https://doi. org/10.1163/156853374X00251.

15. Gardiner, Ancient Egyptian Onomastica II, $2{ }^{*} 3^{*}$. 
on either side of a Nile distributary. ${ }^{16}$ Toponym \#418, which is $p 3$ twfy ${ }^{17}$ and which should be found just south of Tjaru, is precisely where the Ballah Lakes are located.

Another consideration for locating p3 twwfy/ים-סוּ somewhere on the eastern frontier of Sinai concerns the Arabic toponym (Tell) Abu Sefêh, home to the frontier site of Sile from the sixth century BC into the Roman period, on the northern shore of the Ballah Lakes. I have previously argued linguistically that Arabic abu can preserve the ancient Egyptian words $p 3$ or pi and that sè-fee replicates $\underline{t} w f y / s u f .{ }^{18}$ Hence, the name Abu Sefêh appears to preserve the ancient name $p 3$ twfy in Arabic.

As a part of the decade-long (1999-2008) archaeological project at Tell el-Borg, a geological team headed by Stephen Moshier, Professor of Geology at Wheaton College, collaborated with members of the Egyptian Geological Survey to carry out palaeoenvironmental investigations around the site. The results, which included the discovery of a previously unknown Nile distributary that flowed by Tell el-Borg and which emerged from the northern end of the Ballah Lakes, were ground-breaking. It continued east, where it emptied into the so-called eastern or palaeo-lagoon, ${ }^{19}$ that is, Pa-Shihor (Shihor) (Fig. 3).

Moshier, working with Bahaa Gayed of the Geological Survey of Egypt, probed the Ballah depression to lay bare its history. The investigations included drilling down to depths five to seven metres below the surface and resulted in new,

16. D. Valbelle et al., 'Reconnaissance archéologique à la pointe orientale du Delta: Rapport préliminaire sur les saisons 1990 et 1991', CRIPEL 14 (1992), fig. 3; Mohamed Abd elMaksoud, Tell Heboua (1981-1991): Enquête archéologique sur la Deuxième Périod Intermédiaire et le Nouvel Empire à l'extrémité orientale du Delta (Paris: Éditions Recherche sur les Civilisations, 1998), 30-31; Mohamed Abd el-Maksoud, 'Une nouvelle forteresse sur la route d'Horus: Tell Heboua 1986 (Nord Sinaii)', CRIPEL 9 (1987): 13-16; James K. Hoffmeier and Mohamed Abd el-Maksoud, 'A New Military Site on the "Ways of Horus" - Tell El-Borg 1999-2001: A Preliminary Report', JEA 89 (2003): 169-197, https://doi.org/10.1177/030751330308900109; Mohamed Abd el-Maksoud and Dominique Valbelle, 'Tell Héboua-Tjarou: l'apport de l'épigraphie', REg 56 (2005): 7-8, 18-21, https://doi.org/10.2143/RE.56.0.2004950. Regarding Hebua II, see Mohamed Abd el-Maksoud and Dominique Valbelle, 'Tell Héboua II: Rapport préliminaire sur le décor el l'épigraphie des elements architectoniques découverts au cours des campagnes 2008-2009 dans la zone centrale du khétem de Tjarou', REg 62 (2011): 1-39, https://doi.org/10.2143/RE.62.0.2136927.

17. Gardiner, Ancient Egyptian Onomastica II, 202*-203*.

18. James K. Hoffmeier, Ancient Israel in Sinai: The Evidence for the Authenticity of the Wilderness Traditions (New York: Oxford University Press, 2005), 88-89, https://doi. org/10.1093/acprof:oso/0195155467.001.000.

19. Stephen O. Moshier and Ali el-Kalani, 'Late Bronze Age Paleogeography along the Ancient Ways of Horus in Northwest Sinai, Egypt', Geoarchaeology 23 (2008): 450-473, https://doi.org/10.1002/gea.20227. 
important information about the nature and history of this body of water. ${ }^{20}$ This ancient feature can no longer be viewed as just a shallow marshy swamp. Rather, it was a robust lake. Analysis of the sediments show that some deposits were lacustrine and others fluvial in nature, indicating that a Nile distributary fed the lake somewhere on its west side (see Fig. 3). ${ }^{21}$ This Nilotic component to the lake means that its level fluctuated with the Nile's annual flood cycle.

Bietak's 1975 study of the area, based on older topographical maps, showed that the Ballah depression was made up of three smaller depressions or lakes that, during the flood season, could have expanded to merge into one large lake about twenty kilometres long from north to south and at places fourteen to fifteen kilometres wide from east to west. It perhaps even extended further during higher inundations.

Moreover, thanks to subsurface drilling and analysis of the sands and dating of shells, a better picture of the nature of the lake and its history has emerged. ${ }^{22}$ Shells from different levels were collected and carbon dated. Not surprisingly, the deeper the locus of the deposit, the earlier the age of the shells, as Moshier and Gayed report:

A significant shift to much older dates [is] represented in two shells recovered below $2 \mathrm{~m}: 3090 \pm 40 \mathrm{BP}$ at $2.1 \mathrm{~m}$ depth and $3110 \pm 40 \mathrm{BP}$ at $2.6 \mathrm{~m}$ depth. Calibrated to calendar dates, these results represent with $95 \%$ confidence (2 sigma) deposition between 3380-3220 BP and 3390-3240 BP, respectively. These two clusters of dates in the $3 \mathrm{~m}$-thick deposit suggest an initial phase of widespread lacustrine deposition across the depression some 3300 years ago, followed by lake recession over the next two millennia, until a return to more widespread lacustrine conditions after 700 years BP. ${ }^{23}$

The new data indicate that during the New Kingdom and into the Ramesside era, the frontier lakes were thriving. There were riparian wetlands surrounding them, ${ }^{24}$ likely where marshes with thickets of reeds and rushes flourished, as reflected in ancient texts. Evidently it was the nature of this region which inspired the

20. Stephen O. Moshier and Bahaa Gayed, 'Geological Investigation of the Ballah Depression, Northern Suez Canal Zone, Egypt' in Excavations in North Sinai: Tell elBorg II, ed. J. K. Hoffmeier (University Park, PA: Eisenbrauns, 2019), 5-20, https://doi. org/10.1515/9781646020058-005.

21. Moshier and Gayed, 'Geological Investigation', 8-14.

22. Moshier and Gayed, 'Geological Investigation', fig. 2.2 shows a drilling rig in operation under the direction of Dr Bahaa Gayed; fig. 2.8 is a map showing the drilling data points.

23. Moshier and Gayed, 'Geological Investigation', 13.

24. See especially the maps: Tell el-Borg II, Fig. 2:8 and 2:11. 
descriptive name $p 3$ twfy/ים-סוּר. The northern end of the lake was where Tell Abu Sefêh is located. Its harbour and corniche were discovered in the 1990s and date to the Graeco-Roman period, indicating that the waters were still navigable at that time. ${ }^{25}$ The north-eastern limit of the lake extended another three to four kilometres beyond Tell Abu Sefêh.

A number of biblical scholars have thought that $p 3$ twfy was only a marshy or wetland area - not a lake or sea (יָָ). Nearly sixty years ago, Lewis Hay described ים a as a shallow marsh on the north-eastern frontier of Egypt, where Pharaoh's chariots got bogged down in the mud, making the Egyptian force an easy target for Hebrew archers. ${ }^{26}$ Then, Hay speculated, the biblical story was embellished: 'over a period of time the Reed Sea became a tremendous body of water ... ${ }^{27}$ More recently, Marc Vervenne also opined that Egyptian $p 3$ twfy was not a sea, just a marshy region, and then extended this assumption to assert that 'the Egyptian sources themselves would not allow us to identify the territory of $p 3$ twf with ף ${ }^{28}$

Such assertions are pure speculation and without the benefit of any on-site investigation nor palaeoenvironmental work. The recent geological work on the Ballah Lakes corrects these faulty assumptions. According to Moshier and Gayed,

A surveyed transect extending $320 \mathrm{~m}$ from the top of one shoreline bank [near Tell-Abu Sefêh] measured a drop of $3.5 \mathrm{~m}$ over a distance of $100 \mathrm{~m}$, followed by a more gentle slope over the next $220 \mathrm{~m}$ to $5.5 \mathrm{~m}$ below the upper level of the bank ... It is possible that some of the lakes may have approached or exceeded 6-8 $\mathrm{m}$ deep when bank-full. ${ }^{29}$

25. This material awaits publication, but I was present during excavations that exposed the harbour in 1994. In 2018 renewed work by Dr Hesham Hussein in a quay uncovered the hull of a wooden boat. Press reports have appeared: https://www.ancientorigins.net/news-history-archaeology/egyptian-ship-0011470. For a report on the forts uncovered at Tell Abu Sefêh, see M. Abd el-Maksoud, et al., 'The Roman Castrum of Tell Abu Sayfi at Qantara', Mitteilingen des Deutschen Archäologischen Institutes, Abteilung Kairo 53 (1997): 221-226.

26. Lewis Hay, 'What Really Happened at the Sea of Reeds?', JBL 83 (1964): 401-402, https://doi.org/10.2307/3264173.

27. Hay, 'What Really Happened?', 402.

28. M. Vervenne, 'The Lexeme Sûph and the Phrase Yam Sûph: A Brief Reflection on the Etymology and Semantics of a Key Word in the Hebrew Exodus Tradition' in Immigration and Emigration within the Ancient Near East, Festschrift E. Lipinska, ed. K. van Lerberghe and A. Schooks (Leuven: Orientalia Louaniensia Analecta, 1995), 419, 427.

29. Moshier and Gayed, Tell el-Borg II, 7. 
Clearly, the Ballah depression was home to a large lake that, during the wet seasons, spilled over to create marshy wetlands where various types of water plants and reeds grew. To this day there are a few areas west of the Suez Canal where marshy conditions prevail and reeds grow two or three metres in height; meanwhile the area east of the canal is now largely desert. In other words, $p 3$ twfy had a large marshy area that surrounded a lake that was fed by a Nile distributary, but it could have been reduced to three smaller lakes during the dry season.

Two additional geographical notes might help elucidate the location described in Exodus 14:1-2. Thanks to the discovery of the aforementioned defunct north Sinai Nile channel, which runs east into the eastern lagoon (Pa-Shihor), about fifteen kilometres away, we have a possible feature that might correspond to Pihahiroth (Exod. 14:2). As suggested above, based on Pap. Anastasi III (2,11-12), the two bodies of water - $p 3 \underline{t} w f y$ and $p 3 \check{s}$ - hr $r$ - occur in parallelism, and then lines 2.8-9 add that 'Pa-Shihor has salt and the channel has natron. Its boats set out and moor.' ${ }^{30}$ The word I render as 'channel' is $p 3$ hry, written with two classifiers, the water sign ( $\underset{\mathrm{mm}}{\mathrm{mm}}$ ) and the channel filled with water $(\Sigma) \cdot{ }^{31}$ This combination of indicators is used with names of rivers, lakes, and seas. ${ }^{32}$ Ricardo Caminos was at a loss to explain the feature and therefore only transliterated this term in his translation. The p3-hrr waters, he suggested in his commentary, were "perhaps a canal'. ${ }^{33}$ James Allen in Context of Scripture renders $p 3$ hw 'canal', ${ }^{44}$ proposing that the term hw-ir derives from the Semitic word harra, and hrt in Old South Arabian means 'irrigation canal'. ${ }^{35}$ Previously, I too had suggested that פִִּ הַחיר (pi hakhiroth) might correspond to Akkadian herû, which means 'to dig (with a hoe)', 'to groove'; harru means 'water course', and in the Kassite period (1600-1200 BC) herūtu is applied to ditches and canals. ${ }^{36}$

Cִִּּ הַחירת in Exodus 14:2? It could be rendered as 'the mouth of the canal/channel' from

30. Translation my own, based on Gardiner, Late Egyptian Miscellanies, 22.9-10.

31. Alan Gardiner, Egyptian Grammar (London: Oxford University Press, 1969), signs N 35 and $\mathrm{N} 36$.

32. Gardiner, Egyptian Grammar, 491.

33. Ricard Caminos, Late Egyptian Miscellanies (London: Oxford University Press, 1954), $74,78$.

34. COS III, 15. p3 hw-ir occurs again in Anastasi III 3, 4, but adds nothing to its location.

35. Allen bases his observation on James E. Hoch's analysis of the word in Semitic Words in Egyptian Texts of the New Kingdom and Third Intermediate Period (Princeton: Princeton University Press, 1994), §322, https://doi.org/10.1515/9781400863884.

36. See CAD 6, 175 and my discussion in James K. Hoffmeier, Israel in Egypt (New York: Oxford University Press, 1996), 168-170. 
Hebrew then possibly it means 'the canal or channel' ${ }^{37}$ Commenting on this feature, Allen describes it as the "name of a navigable, brackish body of water in the eastern Egyptian Delta, perhaps joining an arm of the Nile to the Lake of Horus' ${ }^{38}$ The connection between the Tell el-Borg channel and the eastern lagoon (i.e. Shihor) is an intriguing possibility.

In the line preceding the references to $p 3 \check{s}$ - $h r$ and $p 3 h w$-ir in Pap. Anastasi III, another body of water is introduced, although the text contains a lacuna, making the exact reading uncertain. But the passage is dealing with various types of fish in the different canals, channels, and lakes in the eastern Delta. Pap. Anastasi III 2,8 reports that there are mullet in a body of water whose name is lost (only the determinatives are legible: $\stackrel{m=1}{\square}=$ ) - a lake or channel which 'belongs to Baal' ( 14:2? It has been thought that the toponym Baal-Zaphon was associated with Tell Deffeneh (Tahpanes) ${ }^{39}$ or Mount Cassius on Lake Sirbonis/Bardawil,${ }^{40}$ though archaeological evidence to support these proposals is lacking. Once again, the combination of signs indicates that it was a body of water, perhaps a small lake, of which there were several in this area.

The Egyptian textual evidence, coupled with the toponymic sequence in the Exodus and Numbers 33 itineraries - showing only two campsites before reaching ,ים־־וּף the third stop - demonstrates that it was located close to Egypt, if not on its frontier with Sinai. Recently, Barry Beitzel has made a sustained and compelling case for this view against those advocating that ים-סוּ in the Exodus narratives is the distant Gulf of Aqaba. ${ }^{41}$

The next observation related to identifying the location of ים-סיר is based on the recently discovered New Kingdom forts that helped establish in the archaeological record the sequence depicted on the Seti I reliefs at Karnak

37. While linguistically a possible reading, an explanation needs to be sought for the Egyptian and Hebrew definite articles both being written. This problem may favour being the construct for

38. COS III, 15, n. 4.

39. Noël Aimé-Giron, 'Bacal Saphon et les dieux de Tahpanhes dans un nouveau papyrus Phénicien', ASAE (1941): 433-460.

40. Otto Eissfeldt, Baal Zaphon, Zeus Kasios und der Durchzug der Israeliten durchs Meer (Halle: Niemeyer, 1932). Others have followed Eissfeldt's lead: Siegfried Hermann, Israel in Egypt (London: SCM Press, 1973), 60-62; Martin Noth, Exodus (Philadelphia: Westminster, 1962), 109-110.

41. Barry J. Beitzel, Where Was the Biblical Red Sea? Examining Ancient Evidence (Bellingham, WA: Lexham Press, 2020), 17-59. 


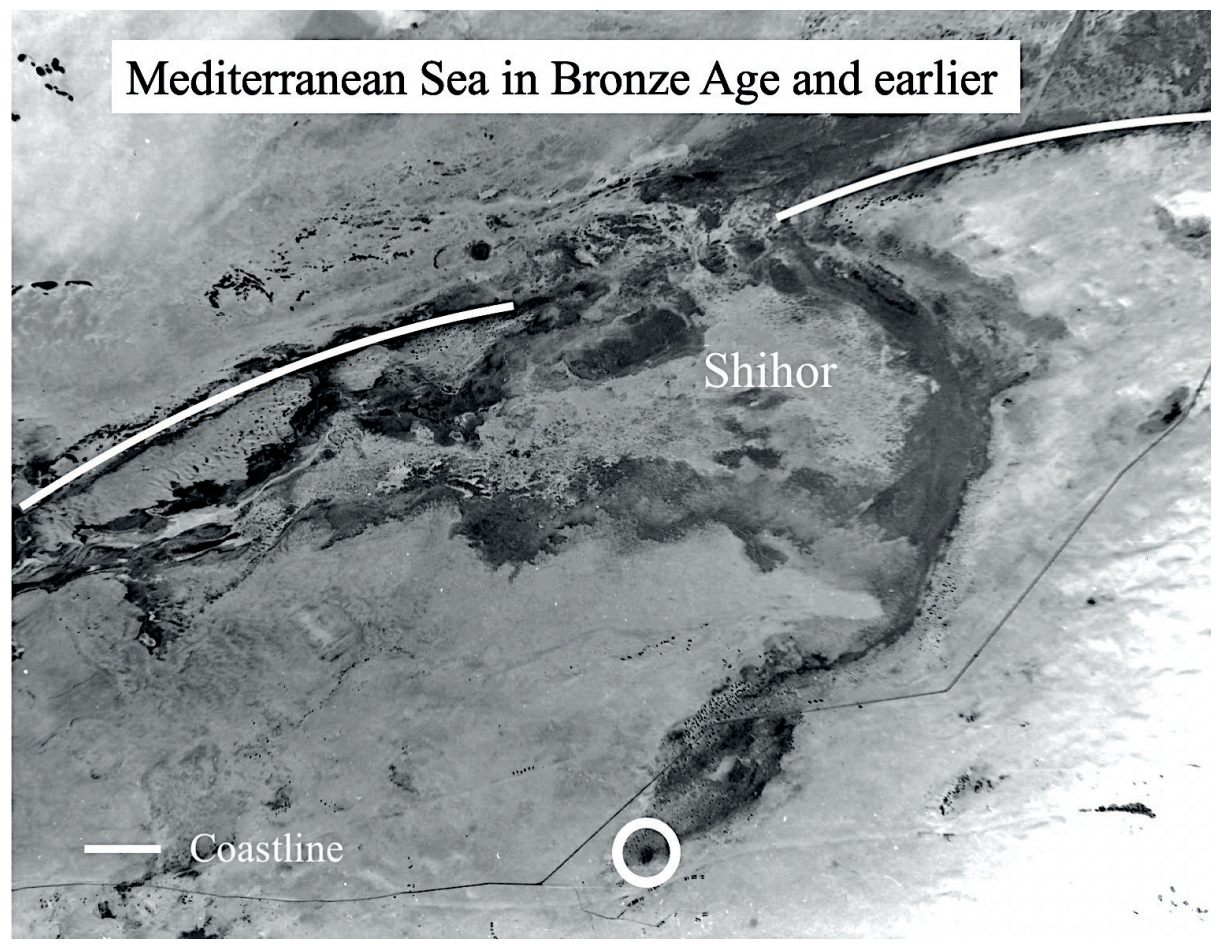

Figure 4a: CORONA Satellite image (December 1967) of Shihor, with the location of site

T-211 circled. (Image: US Geological Survey.)

Temple and documented in Pap. Anastasi I. ${ }^{42}$ According to these two sources, Egypt's fortified frontier town Tjaru at Tell Hebua I and II marked the beginning of the road to Canaan, followed by the Dwelling of the Lion (i.e. Tell el-Borg) ${ }^{43}$ and Migdol of Menmaatre, the latter of which has long been associated with Migdol of Exodus 14:2, ${ }^{44}$ though its location was unknown. When the recent archaeological

42. See Gardiner, 'The Ancient Military Road', 99-116; he did a comparative study of the two sources. For a more up-to-date discussion of the corresponding archaeological sites with the toponyms, see James K. Hoffmeier and Stephen O. Moshier, "The Ways of Horus": Reconstructing Egypt's Eastern Frontier Defense Network and the Military Road to Canaan in New Kingdom Times' in Tell el-Borg I: Excavations in North Sinai, ed. J. K. Hoffmeier (Winona Lake, IN: Eisenbrauns, 2014), 34-61.

43. For the identification of Tell el-Borg with the Dwelling of the Lion/Ramesses, see James K. Hoffmeier and Mohamed Abd el-Maksoud, 'A New Military Site on "the Ways of Horus” - Tell el-Borg 1999-2001: A Preliminary Report', JEA 89 (2003): 169-197.

44. Gardiner, 'The Ancient Military Road', 107-109; J. P. Hyatt, Exodus, New Century Bible Commentary (London: Marshall, Morgan \& Scott, 1971), 150-151; Benjamin E. Scolnic, 'A New Working Hypothesis for the Identification of Migdol' in The Future of Biblical Archaeology: Reassessing Methodologies and Assumptions, ed. J. K. Hoffmeier and A. R. Millard (Grand Rapids: Eerdmans, 2004), 109-120; James K. Hoffmeier, 'The Search for Migdol of the 


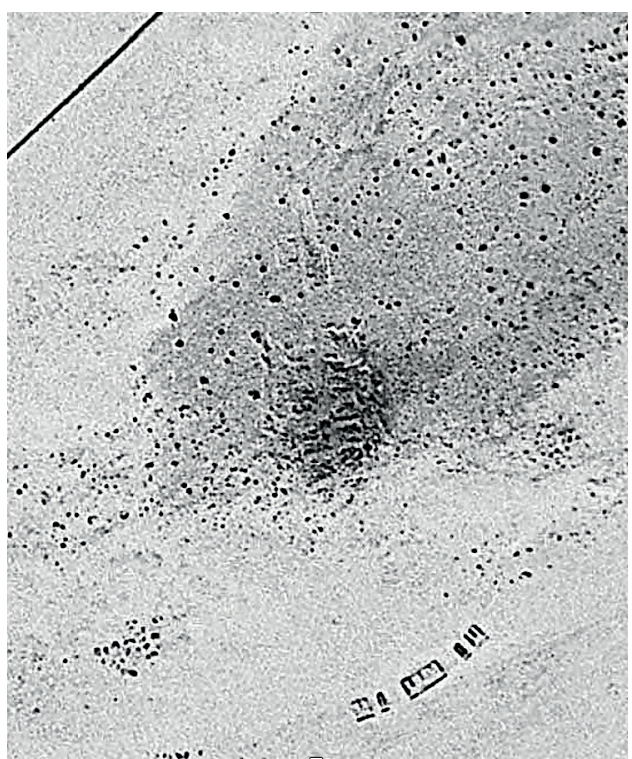

Figure 4b: Closeup of T-211 at the southern tip of the palaeo-lagoon (Shihor) from Fig. 4 a.

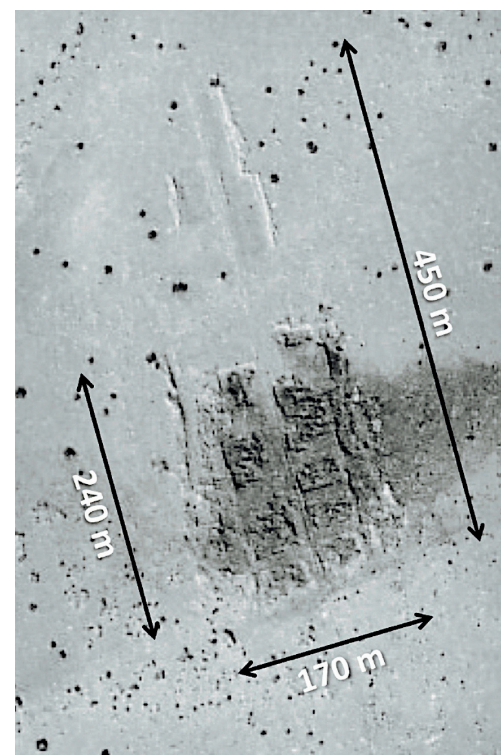

Figure 5: Aerial image of T-211.

(Geological Survey of Egypt, courtesy of Dr Bahaa Gayed.)

and palaeoenvironmental work are combined, it appears that second-millennium BC (Late Bronze Age) Migdol was located at the southern tip of Shihor. There, Eliezer Oren's survey discovered a New Kingdom period site he labelled T-211.45 By examining an enlarged CORONA satellite image from 1967, the outline of a rectangular feature is evident (Figs 4a-b). An earlier aerial photograph from 1957 clearly reveals the walls of a fort along with concave lines that appear to be a moat (Figs 4a-b, 5). ${ }^{46}$ Consequently, in this area, between the Suez Canal at Qantara and about fourteen kilometres to the east (where the proposed location of Migdol is at the southern end of Shihor), we have the collocation of four toponyms mentioned in Exodus 14:2, viz, p3 twwfy/ים־סוּף, Pi-hahiroth, Baal (Zaphon?), and Migdol. Site $\mathrm{T}-211$ is located about eight or nine kilometres north-east of the northern end of

New Kingdom and Exodus 14:2: An Update', Buried History 44 (2008): 3-12; idem., 'A Possible Location in Northwest Sinai for the Sea and Land Battles between the Sea Peoples and Ramesses III', BASOR 380 (2018): 1-25, https://doi.org/10.5615/bullamerschoorie.380.0001.

45. In 2007 , I led a group of my staff to locate this site, armed with the coordinates courtesy of Eliezer Oren. In the past decade, however, the entire area had been covered with a metre of sand and turned into a fruit plantation. No remains were visible.

46. For a discussion of these images and the suggestion that T-211 corresponds to the Egyptian fort Migdol, see James K. Hoffmeier, 'The Curious Phenomenon of Moving Military Sites on Egypt's Eastern Frontier', JSSEA 45 (2018/19): 105-134; Joffrey Seguin, Le Migdol du Proche-Orient à l'Égypt (Paris: Sorbonne University, 2007), 117-122. 


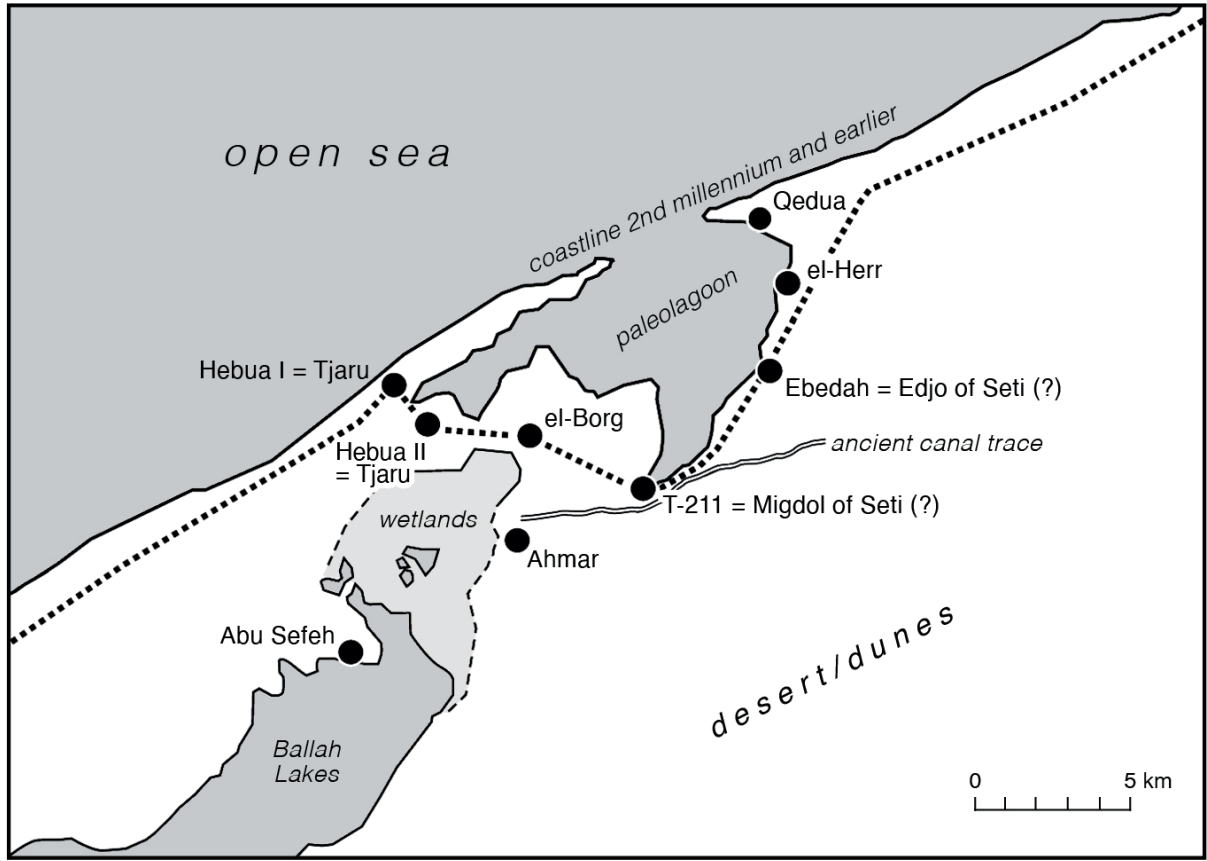

Figure 6: Map of area around the palaeo-lagoon/Shihor. (Adapted by A. D. Riddle from a map by Stephen Moshier, digitized by Jessica Hoffmeier Lim.)

the Ballah Lakes. These places date squarely in the Ramesside era, the final third of the second millennium BC. ${ }^{47}$

During the New Kingdom or Late Bronze Age (ca. 1500-1200 BC) and earlier, two Nile distributaries fed this eastern lagoon (Shihor), and in its northern reaches it debouched into the Mediterranean. This lagoon was approximately eight by eight kilometres, meaning that travelling towards the Levant and launching a journey from Tjaru/Sile required travellers to circle south around Shihor before turning east and following the coast to Gaza (see Fig. 6). Starting in the thirteenth century $\mathrm{BC}$, due to reduced volume of the Nile, some of the eastern branches began to desiccate, including those that fed shihor, resulting in the lagoon being reduced to a smaller, brackish lake. Geographer Karl Butzer pointed out that in the twelfth century Nile inundations were dangerously low: a 'catastrophic failure

47. Many years ago, Henri Cazelles noticed the correspondence between the Exodus toponyms and those in Pap. Anastasi III, but could not at that time establish their locations as little was known about the archaeological sites in the area beyond Tell Abu Sefêh and Tell el-Herr, both of which are later period sites. See 'Les localisations de l'Exode et la critique littéraire', RB 62 (1955): 346-358. 
in the annual flood'. ${ }^{48}$ The geologist Rushdi Said explained that there were 'lower discharges' of the Nile beginning late in the reign of Ramesses II. ${ }^{49}$

The impact of lower Nile levels is described in Pap. Anastasi VIII, ${ }^{50}$ in a letter (not a practice text) written by the scribe Ramose who died during Ramesses II's thirty-ninth year (ca. $1240 \mathrm{BC}$ ), meaning that the conditions described herein date to the 'middle of reign of Ramesses II', as Sarah Groll suggests. ${ }^{51}$ Ramose reports on the drought-like conditions of the $p 3$ twfy region, ${ }^{52}$ explaining that the regular shipments of vegetation products from the eastern frontier could not be made (recto III, 11. 11-14). Groll concludes that 'this lush region has apparently suffered an ecological catastrophe'. ${ }^{53}$ The reduced flow of the Nile and poor inundations eventually led to the silting up of sections of the Bubastite Nile distributary. This, in turn, resulted in the abandonment of the Delta capital, Pi-Ramesses, around $1130 \mathrm{BC} .{ }^{54}$

\section{Jeremiah's Eisodus}

By the Third Intermediate Period (1069-525 BC), Shihor clearly still contained water, as demonstrated by the fact that no archaeological sites have been discovered within the basin, even from as late as Roman, Byzantine, or Islamic periods. Shihor's water in Jeremiah's day, therefore, was largely brackish and stagnant, and due to continued desiccation, the opening to the Mediterranean was closed. Meanwhile, the coast and Pelusiac Nile migrated north of the Bronze Age coastline as the delta plain expanded north and east. When Jeremiah 2:18 mentions Shihor in parallelism with the Euphrates, it is because both bodies of water served as a natural boundary marker to the respective lands of Assyria and Egypt.

48. Karl Butzer, Early Hydraulic Civilization in Egypt: A Study in Cultural Ecology (Chicago: University of Chicago Press, 1976), 56.

49. Rushdi Said, The River Nile: Geology, Hydrology and Utilization (Oxford: Pergamon, 1993), 150.

50. For the text, see K. A. Kitchen, Ramesside Inscriptions, Historical and Biographical III (Oxford: Blackwells, 1980), 499-504. For commentary and discussion of this text, see Sarah I. Groll, 'The Egyptian Background of the Exodus and the Crossing of the Reed Sea: A New Reading of Papyrus Anastasi VIII' in Jerusalem Studies in Egyptology, ed. I. Shirun-Grumach (ÄAT 40: Wiesbaden: Harrasowitz Verlag, 1998), 173-192.

51. Groll, 'The Egyptian Background', 190.

52. Groll, 'The Egyptian Background', mentioned on p. 173, note *.

53. Groll, 'The Egyptian Background', 190.

54. For a detailed discussion of the landscape changes due to Nilotic and seismic factors, see James K. Hoffmeier, 'The Curious Phenomenon of Moving Military Sites on Egypt's Eastern Frontier', JSSEA 36 (2018/19): 105-134. 


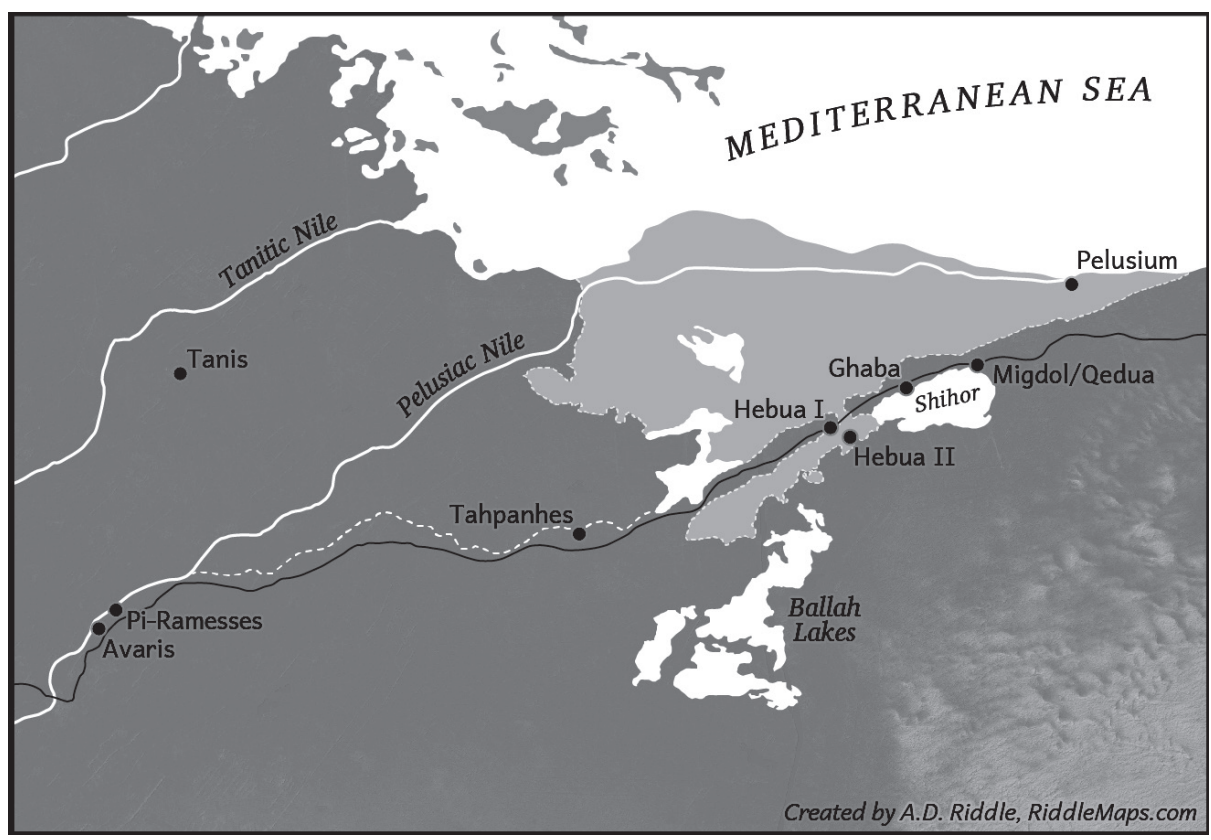

Figure 7: Map of the region around the palaeo-lagoon/Shihor during the first millennium $\mathrm{BC}$ showing Jeremiah's route into Egypt.

It can be inferred from Jeremiah 44:1 and 46:14 that the Judaean refugees, including Jeremiah and Baruch, who arrived in Egypt in 582 BC, passed by Migdol. On the north-eastern shore of Shihor stood a large fortress at Tell Qedua that Oren excavated and identified as Migdol of Jeremiah $(44: 1 ; 46: 14)$ and Ezekiel (29:10; 30:6) (Fig. 6). ${ }^{55}$ The Qedua fortress, measuring about 200 metres by 200 metres, with walls 11 metres thick (up to 17.5 metres where the towers stood), was the military checkpoint for access to Egypt along the coastal road, and the most recent work by Hesham Hussein and Elsayid Abdel Alim has shown that on the eastern side the walls were reinforced, widened to 25 metres. ${ }^{56}$ Based on the ceramic evidence, Oren dated the founding of the fort to the Saite period or seventh century; the site was likely abandoned after suffering damage during the Persian invasion of 525 BC. Donald Redford's two brief seasons of work at Qedua confirmed Oren's earlier dating of the site, but he thinks there was some

55. Eliezer D. Oren, 'Migdol: A New Fortress on the Edge of the Eastern Nile Delta', BASOR 256 (1984): 14, https://doi.org/10.2307/1356923.

56. Hesham Hussein and Elsayid Abdel Alim, 'The Way(s) of Horus in the Saite Period: Tell el-Kedwa and Its Key Location Guarding Egypt's Northeastern Frontier', Journal of Ancient Egyptian Interconnections 7 (2015): 43-44. 
occupation after $525 \mathrm{BC} .^{57}$ While a Saite date $(664-610 \mathrm{BC})^{58}$ is generally assigned to the origins of this fort, a reference to 'Migdol' in the records of Esarhaddon during his invasion of Egypt in $671 \mathrm{BC}$ suggests that a possible earlier, twentyfifth-Dynasty date for its construction - in anticipation of the Assyrian invasions of Egypt - is a possibility. ${ }^{59}$

About five kilometres west of Qedua/Migdol sits Tell Ghaba, which was founded as early as the tenth century and occupies a spot on the inside of a barrier island close to the lagoon's mouth (Fig. 7).$^{60}$ It is doubtful that this site could have flourished at this location during the New Kingdom, when the lagoon was fed by two free-flowing distributaries. Tell Hebua is situated seven kilometres west of Ghaba. A fort with walls 10 metres thick stood at Hebua I, while Hebua II has a Saite-period settlement within the old New Kingdom-fortified wall ${ }^{61}$ that had in earlier centuries been Egypt's major border fort (htm $n t 3 r w)$.

Recently, two historically significant stelae of Apries/Hophra (589-570 BC) were discovered at Tell Deffeneh (Tahpanhes). The first stela was discovered in 2011 by Mohamed Abd el-Maksoud and dates to Apries' seventh year (582 BC). ${ }^{62}$ This is the same year as year twenty-three of Nebuchadnezzar, when his forces struck the remnant of Judah after Gedaliah's assassination (cf. Jer 52:30). The stela reports that the king himself and his armies travelled on 'the road to the east' across Sinai (line 4), the goal being 'to smite Asiatics' (line 3). Apparently, after the mop-up operations in Judah and the Transjordan - Abd el-Maksoud and Valbelle suggest - the Chaldeans intended to invade Egypt. ${ }^{63}$ The second

57. Donald B. Redford, 'Report on the 1993 and 1997 Seasons at Tell Qedwa', JARCE 35 (1998): 51, https://doi.org/10.2307/40000460.

58. These are the dates for the long-reigning king Psammetichus I. See K. A. Kitchen, The Third Intermediate Period in Egypt: 1100-650 B.C., 2nd ed. (Warminster: Aris \& Phillips, 1986), 468.

59. In his commentary on this text, Mordechai Cogan (The Raging Torrent: Historical Inscriptions from Assyria and Babylonia Relating to Ancient Israel (Jerusalem: Carta, 2008), 147) suggests that this Migdol might be the fort at Tel Qedua.

60. Perla Fuscaldo, Tell el-Ghaba II: A Saite Settlement in North Sinai Egypt (Argentine Archaeological Mission, 1995-2004) (Buenos Aires: Consejo Nacional de Investigaciones Científicas y Técnicas, 2006); Silvia Lupo and Claudia Kohen, Tell el-Ghaba III: A Third Intermediate-Early Saite Period Site in the Egyptian Eastern Delta: Excavations 1995-1999 and 2010 in Areas I, II, VI and VIII (Oxford: BAR, 2015), https://doi.org/10.30861/9781407314174.

61. Elsayed Abdel-Alim, 'Tell Habua: New Discoveries from the Saite Period', Egyptian Archaeology 56 (2020): 10-15.

62. Mohamed Abd el-Maksoud and Dominique Valbelle, 'Une stèle de l'an 7 d'Apries découverte sur le site de Tell Défenneh', REg 64 (2013): 1-13, https://doi.org/10.2143/ RE.64.0.3011326.

63. Abd el-Maksoud and Valbelle, 'Une stèle', 10-12. 
stela was discovered in May 2021 during the writing of this paper. Based solely on pictures of the stela in the press, one has only been able to study the text cursorily. Nevertheless, one can see that the inscription likewise treats the same military expedition and also mentions traversing Sinai with armies and horses. The campaign was presumably launched from Tahpanhes. The new inscription mentions passing by Tjaru/Sile $(\underline{t} 3 r w)$, which demonstrates that the army was traversing the road from Tahpanhes to Migdol in order to reach the southern Levant. By mentioning Tjaru it seems that Apries may have been trying to identify with great predecessors like Thutmose III and Ramesses II, who launched their famous campaigns to Megiddo and Kadesh from Tjaru. Hophra's army would have checked in at Migdol, where additional troops were likely added for the campaign across Sinai to discourage the Chaldeans from attempting to invade Egypt. This same route would also have been taken by Esarhaddon's armies and by Jeremiah and the band of Judaean refugees entering Egypt (Fig. 7).

About twenty kilometres west of Tjaru sits Tell Deffeneh (or Dafana). This site is identified with Tahpanhes (Jer 44:1) and is also a military site. ${ }^{64}$ Here, according to Herodotus, Psammetichus I (664-610 BC) established a military base to defend Egypt from invasions from western Asia. ${ }^{65}$ It was at this site that Jeremiah delivered his blistering message, criticising those who had come to Egypt for refuge and warning that Nebuchadnezzar would invade (Jer 44). In addition to addressing his fellow countrymen who resided at Migdol and Tahpanhes, Jeremiah mentions those in Memphis, Egypt's traditional capital at the base of the Delta, where Apries built a palace and fortress. ${ }^{66}$ Lastly, Jeremiah mentions Pathros, which corresponds to Egyptian $p 3 t 3$ rsy, 'the south land', i.e. Upper Egypt. ${ }^{67}$ Ezekiel, writing about the same time as Jeremiah in distant Babylon, refers to Egypt's territory as being Migdol to Syene, i.e. Aswan (Ezek 29:10; 30:6), both being fortified frontier sites.

This range of toponyms indicates that Judaeans were located from Egypt's northern frontier all the way to the border with Kush (Nubia). All the locations mentioned by Jeremiah had military installations where Judaean mercenaries likely served, as suggested by the Aramaic papyri of the Jewish community of

64. Kvĕta Smoláriková, Saite Forts in Egypt: Political-Military History of the Saite Dynasty (Prague: Charles University, 2008), 77-82; François Leclère, 'Tell Dafana: Identity, Explorations and Monuments' in Tell Dafana Reconsidered: The Archaeology of an Egyptian Frontier Town, ed. F. Leclère and A. J. Spencer (London: The British Museum, 2014), 1-40.

65. Herodotus reports that Psammetichus I stationed troops at Elephantine and Daphne (Tahpanhes); Herodotus and the Histories, trans. Walter Blanco and Jennifer T. Roberts (New York: Norton, 1992), 83.

66. Smoláriková, Saite Forts, 55-65.

67. Muchiki, Egyptian Proper Names, 234-235. 
Elephantine Island in Aswan. ${ }^{68}$ It appears then that many of the Judaeans who had fled to Egypt were deserting soldiers whose services were marketable in Saite Egypt. Its armies included many mercenaries, Herodotus reports. ${ }^{69}$ The 2011 Apries stela seemingly supports this claim by referring to 'foreigners (h3styw) who accompanied his majesty' (line 5), and Jeremiah too mentions the hired soldiers among Egypt's troops (Jer 46:21). ${ }^{70}$ Incorporating Judaean soldiers as mercenaries into the Egyptian army was a natural move. Ironically, some of these soldiers may well have had to fight against Nebuchadnezzar's forces during his successful invasion of Egypt in 568 BC.

\section{Conclusions}

Egypt's north-eastern frontier was a maze of lakes, wetlands, Nile distributaries, and sand dunes with forts situated in strategic locations to guard land and sea access to Egypt. ${ }^{71}$ Through this zone between Egypt's delta and Sinai passed the coastal highway that led from Egypt to Canaan. Due to the militarised nature of the region, the Hebrews avoided this means of egress (Exod 13:17). The Israelites, therefore, headed south-east towards the Wadi Tumilat (Exod 13:18). But at the edge of the Sinai wilderness at the end of the Wadi, God instructed them to turn

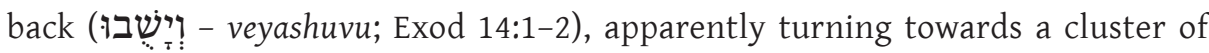
toponyms that appear to be near the area around the northern end of $p 3$ twfy and the southern tip of Shihor.

The recent archaeological and geological investigations in north Sinai now permit us to peer back three and four millennia to understand the ancient landscape. Now we can say with certainty that if $p 3$ twfy/oים was the sea traversed by the escaping Hebrews, it was a large lake with deep waters, surrounded by wetlands consisting of reeds and rushes, which resulted in the descriptive name of the area and the lake.

With the passage of the centuries between the days of the exodus and Jeremiah, major environmental changes occurred in this same zone when the Nile

68. The Aramaic Papyri from Elephantine attest to the presence of the Jewish community, including correspondence between a Jewish man and his son who was a soldier at Migdol. See Bezalel Porten, The Elephantine Papyri in English (Atlanta: SBL, 2011), 108-110. See also Edward Bleiberg, Jewish Life in Ancient Egypt (Brooklyn: Brooklyn Museum of Art, 2002).

69. Herodotus and the Histories, 83.

70. See further James K. Hoffmeier, 'A New Insight on Pharaoh Apries from Herodotus, Diodorus and Jeremiah 46:17', JSSEA 11 (1981): 165-170.

71. Hoffmeier, 'Reconstructing Egypt's Eastern Frontier', 163-194. 
distributaries that fed Shihor were diminished. Consequently, the earlier route around southern Shihor was abandoned when it became an enclosed lake and a new road was established across the old barrier island that formed the Bronze Age coast where the earlier opening to the Mediterranean had become terra firma. This development allowed a more direct road to go from Migdol (Tell Qedua), the entry checkpoint, to Tell Ghaba and the fort at Tjaru, followed by Daphne/ Tahpanhes, where Jeremiah received the word of the LORD and preached his message (Jer 44:1-30). There, he warned that Apries/Hophra would be given into the hand of his enemy. ${ }^{72}$ Interestingly, this new and more direct route was taken by Jeremiah and the fleeing Judaeans (Jer 43:7-8; 44:1) probably just before, in 582 $\mathrm{BC}$, the Egyptian armies marched east to prevent a Chaldean invasion of Egypt.

\section{Bibliography}

Abd el-Maksoud, Mohamed. 'Une nouvelle forteresse sur la route d'Horus: Tell Heboua 1986 (Nord Sinaï)'. CRIPEL 9 (1987): 13-16.

—. Tell Heboua (1981-1991): Enquête archéologique sur la Deuxième Périod Intermédiaire et le Nouvel Empire à l'extrémité orientale du Delta. Paris: Éditions Recherche sur les Civilisations, 1998.

Abd el-Maksoud, M., M. K. Ibrahim, R. H. Mohamed, and P. Grossmann. 'The Roman Castrum of Tell Abu Sayfi at Qantara'. Mitteilingen des Deutschen Archäologischen Instituts, Abteilung Kairo 53 (1997): 221-226.

Abd el-Maksoud, Mohamed and Dominique Valbelle. 'Tell Héboua-Tjarou: l'apport de l'épigraphie'. REg 56 (2005): 1-44. https://doi.org/10.2143/RE.56.0.2004950.

— - 'Tell Héboua II: Rapport préliminaire sur le décor el l'épigraphie des elements architectoniques découverts au cours des campagnes 2008-2009 dans la zone centrale du khétem de Tjarou'. REg 62 (2011): 1-39. https://doi.org/10.2143/RE.62.0.2136927.

— . 'Une stèle de l'an 7 d'Apries découverte sur le site de Tell Défenneh'. REg 64 (2013): 1-13. https://doi.org/10.2143/RE.64.0.3011326.

Abdel-Alim, Elsayed. 'Tell Habua: New Discoveries from the Saite Period'. Egyptian Archaeology 56 (2020): 10-15.

Aimé-Giron, Noël. 'Ba'al Saphon et les dieux de Tahpanhes dans un nouveau papyrus Phénicien'. ASAE (1941): 433-460.

Beitzel, Barry J. Where Was the Biblical Red Sea? Examining Ancient Evidence. Bellingham, WA: Lexham Press, 2020.

Bietak, Manfred. Tell el Dab'a II. Vienna: Österreichische Akademie der Wissenschaften, 1975. - Avaris, the Capital of the Hyksos: Recent Excavations at Tell el-Dab'a. London: The British Museum, 1996.

72. For further discussion of Jeremiah's prophecies against Hophra, see Hoffmeier, 'A New Insight on Pharaoh Apries'. 
- 'On the Historicity of the Exodus: What Egyptology Today Can Contribute to Assessing the Biblical Account of the Sojourn in Egypt'. Pages 17-37 in Israel's Exodus in Transdisciplinary Perspective: Text, Archaeology, Culture, and Geoscience. Edited by T. E. Levy, T. Schneider, and W. H. C. Propp. Cham: Springer, 2015. https://doi.org/10.1007/978-3319-04768-3_2.

Bleiberg, Edward. Jewish Life in Ancient Egypt. Brooklyn: Brooklyn Museum of Art, 2002.

Brugsch, Heinrich. Hieroglyphische-Demotisches Wörterbuch IV. Leipzig: J. C. Hinrichs, 1868.

Butzer, Karl. Early Hydraulic Civilization in Egypt: A Study in Cultural Ecology. Chicago: University of Chicago Press, 1976.

Caminos, Ricard. Late Egyptian Miscellanies. London: Oxford University Press, 1954.

Cazelles, Henri. 'Les localisations de l'Exode et la critique littéraire'. RB 62 (1955): 321-364.

Cogan, Mordechai. The Raging Torrent: Historical Inscriptions from Assyria and Babylonia Relating to Ancient Israel. Jerusalem: Carta, 2008.

Eissfeldt, Otto. Baal Zaphon, Zeus Kasios und der Durchzug der Israeliten durchs Meer. Halle: Niemeyer, 1932.

Fuscaldo, Perla. Tell el-Ghaba II: A Saite Settlement in North Sinai Egypt (Argentine Archaeological Mission, 1995-2004). Buenos Aires: Consejo Nacional de Investigaciones Científicas y Técnicas, 2006.

Gardiner, Alan H. 'The Ancient Military Road Between Egypt and Palestine'. JEA 6 (1920): 99-116. https://doi.org/10.1177/030751332000600112.

_. Late-Egyptian Miscellanies. Bibliotheca Aegyptiaca 7. Brussels: Fondation Égyptologique Reine Élisabeth, 1937.

—. Ancient Egyptian Onomastica II. London: Oxford University Press, 1947.

- Egyptian Grammar. London: Oxford University Press, 1969.

Groll, Sarah I. 'The Egyptian Background of the Exodus and the Crossing of the Reed Sea: A New Reading of Papyrus Anastasi VIII'. Pages 173-192 in Jerusalem Studies in Egyptology. Edited by I. Shirun-Grumach. ÄAT 40. Wiesbaden: Harrasowitz Verlag, 1998.

Har-el, Menashe. The Sinai Journeys: The Route of the Exodus. Los Angeles: Ridgefield Publishing, 1983.

Hay, Lewis. 'What Really Happened at the Sea of Reeds?' JBL 83 (1964): 397-403. https://doi. org/10.2307/3264173.

Hermann, Siegfried. Israel in Egypt. London: SCM Press, 1973.

Herodotus. Herodotus and the Histories. Translated by Walter Blanco and Jennifer T. Roberts. New York: Norton, 1992.

Hoch, James E. Semitic Words in Egyptian Texts of the New Kingdom and Third Intermediate Period. Princeton: Princeton University Press, 1994. https://doi.org/10.1515/9781400863884.

Hoffmeier, James K. 'A New Insight on Pharaoh Apries from Herodotus, Diodorus and Jeremiah 46:17'.JSSEA 11 (1981): 165-170.

- Israel in Egypt. New York: Oxford University Press, 1996.

- Ancient Israel in Sinai: The Evidence for the Authenticity of the Wilderness Traditions. New York: Oxford University Press, 2005. https://doi.org/10.1093/acprof:oso/0195155467.001.000.

—. 'The Search for Migdol of the New Kingdom and Exodus 14:2: An Update'. Buried History 44 (2008): 3-12

—. 'Reconstructing Egypt's Eastern Frontier Defense Network in the New Kingdom (Late Bronze Age)'. Pages 163-194 in The Power of Walls: Fortifications in Ancient Northeastern Africa. Edited by F. Jesse and C. Vogel. Colloquium Africanum 5; Köln: Heinrich-BarthInstitut, 2013. 
. 'A Possible Location in Northwest Sinai for the Sea and Land Battles between the Sea Peoples and Ramesses III'. BASOR 380 (2018): 1-25. https://doi.org/10.5615/ bullamerschoorie.380.0001.

—. 'The Curious Phenomenon of Moving Military Sites on Egypt's Eastern Frontier'. JSSEA 45 (2018/19): 105-134.

Hoffmeier, James K. and Mohamed Abd el-Maksoud. 'A New Military Site on the "Ways of Horus” - Tell El-Borg 1999-2001: A Preliminary Report'. JEA 89 (2003): 169-197. https:// doi.org/10.1177/030751330308900109.

Hoffmeier, James K. and Stephen O. Moshier. “A Highway Out of Egypt”: The Main Road from Egypt to Canaan'. Pages 485-510 in Desert Road Archaeology in Ancient Egypt and Beyond. Edited by F. Förster and H. Reimer. Africa Praehistorica 27, Köln: Heinrich-Barth-Institut, 2013.

—. "“The Ways of Horus": Reconstructing Egypt's Eastern Frontier Defense Network and the Military Road to Canaan in New Kingdom Times'. Pages 34-61 in Tell el-Borg I: Excavations in North Sinai. Edited by J. K. Hoffmeier. Winona Lake, IN: Eisenbrauns, 2014.

Hussein, Hesham and Elsayid Abdel Alim. 'The Way(s) of Horus in the Saite Period: Tell elKedwa and Its Key Location Guarding Egypt's Northeastern Frontier'. Journal of Ancient Egyptian Interconnections 7 (2015): 39-51.

Hyatt, J. P. Exodus, New Century Bible Commentary. London: Marshall, Morgan \& Scott, 1971. Kitchen, K. A. Ramesside Inscriptions, Historical and Biographical III. Oxford: Blackwells, 1980.

- The Third Intermediate Period in Egypt: 1100-650 B.C. 2nd ed. Warminster: Aris \& Phillips, 1986.

Lambdin, Thomas O. 'Egyptian Loan Words in the Old Testament'. JAOS 73 (1953): 145-155. https://doi.org/10.2307/595204.

Leclère, François. 'Tell Dafana: Identity, Explorations and Monuments'. Pages 1-40 in Tell Dafana Reconsidered: The Archaeology of an Egyptian Frontier Town. Edited by F. Leclère and A. J. Spencer. London: The British Museum, 2014.

Lupo, Silvia and Claudia Kohen. Tell el-Ghaba III: A Third Intermediate-Early Saite Period Site in the Egyptian Eastern Delta: Excavations 1995-1999 and 2010 in Areas I, II, VI and VIII. Oxford: BAR, 2015. https://doi.org/10.30861/9781407314174.

Moshier, Stephen O. and Ali el-Kalani. 'Late Bronze Age Paleogeography along the Ancient Ways of Horus in Northwest Sinai, Egypt'. Geoarchaeology 23 (2008): 450-473. https://doi. org/10.1002/gea.20227.

Moshier, Stephen O. and Bahaa Gayed. 'Geological Investigation of the Ballah Depression, Northern Suez Canal Zone, Egypt'. Pages 5-20 in Excavations in North Sinai: Tell el-Borg II. Edited by J. K. Hoffmeier. University Park, PA: Eisenbrauns, 2019. https://doi. org/10.1515/9781646020058-005.

Muchiki, Yoshiyuki. Egyptian Proper Names and Loanwords in North-West Semitic. Atlanta: Society of Biblical Literature, 1999.

Müller, Max. 'A Contribution to the Exodus Geography'. Proceedings of the Society of Biblical Archaeology 10 (1888): 467-477.

Noth, Martin. Exodus. Philadelphia: Westminster, 1962.

Oren, Eliezer D. 'Migdol: A New Fortress on the Edge of the Eastern Nile Delta'. BASOR 256 (1984): 7-44. https://doi.org/10.2307/1356923.

Porten, Bezalel. The Elephantine Papyri in English. Atlanta: SBL, 2011.

Rainey, Anson. The Sacred Bridge. Jerusalem: Carta, 2006.

Redford, Donald B. 'Report on the 1993 and 1997 Seasons at Tell Qedwa'. JARCE 35 (1998): 45-60. https://doi.org/10.2307/40000460. 
Said, Rushdi. The River Nile: Geology, Hydrology and Utilization. Oxford: Pergamon, 1993.

Scolnic, Benjamin E. 'A New Working Hypothesis for the Identification of Migdol'. Pages 91120 in The Future of Biblical Archaeology: Reassessing Methodologies and Assumptions. Edited by J. K. Hoffmeier and A. R. Millard. Grand Rapids: Eerdmans, 2004.

Seguin, Joffrey. Le Migdol du Proche-Orient à l'Égypt. Paris: Sorbonne University, 2007.

Smoláriková, Kvĕta. Saite Forts in Egypt: Political-Military History of the Saite Dynasty. Prague: Charles University, 2008.

Stewart, Christopher, Kris Lemmens, and Maura Sala. 'Satellite Radar in Support to Archaeological Research in Egypt: Tracing Ancient Tracks Between the Southern Levant Across North Sinai'. Archaeological Heritage and Multidisciplinary Egyptological Studies 2 (2015): 199-221.

Valbelle, Dominique. 'La (les) route(s)-d'Horus'. Pages 379-386 in Hommages à Jean Leclant, vol. 4. Edited by C. Berger, G. Clerc, and N. Grimal. Cairo: IFAO, 1994.

'One More Time - “The Ways of Horus”'. Pages 1607-1613 in Guardian of Ancient Egypt: Studies in Honor of Zahi Hawass, vol. 3. Edited by J. Kramin et. al. Prague: Charles University, 2020.

Valbelle, D., F. Le Saout, M. Chartier-Raymond, M. Abd el-Samie, C. Traunecker, G. Wagner, Y.Y. Carrez-Maratray, and P. Zignani. 'Reconnaissance archéologique à la pointe orientale du Delta: Rapport préliminaire sur les saisons 1990 et 1991'. CRIPEL 14 (1992): 11-22.

Vervenne, M. 'The Lexeme Sûph and the Phrase Yam Sûph: A Brief Reflection on the Etymology and Semantics of a Key Word in the Hebrew Exodus Tradition'. Pages 403-429 in Immigration and Emigration within the Ancient Near East, Festschrift E. Lipinska. Edited by K. van Lerberghe and A. Schooks. Leuven: Orientalia Louaniensia Analecta, 1995.

Ward, William. 'The Biconsonantal Root $S p$ and the Common Origin of Egyptian čWf and the Hebrew Sûp: "Marsh(-Plant)"'. VT 24 (1974): 339-349. https://doi. org/10.1163/156853374X00251. 